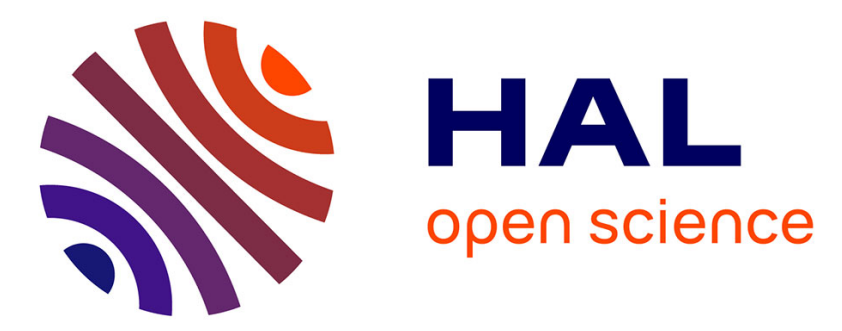

\title{
Laser assisted machining: process control based on real-time surface temperature measurements
}

\author{
M. Ignatiev, L. Okorokov, I. Smurov, V. Martino, G. Bertolon, G. Flamant
}

\section{To cite this version:}

M. Ignatiev, L. Okorokov, I. Smurov, V. Martino, G. Bertolon, et al.. Laser assisted machining: process control based on real-time surface temperature measurements. Journal de Physique IV Proceedings, 1994, 04 (C4), pp.C4-65-C4-68. 10.1051/jp4:1994412 . jpa-00252570

\section{HAL Id: jpa-00252570 https://hal.science/jpa-00252570}

Submitted on 1 Jan 1994

HAL is a multi-disciplinary open access archive for the deposit and dissemination of scientific research documents, whether they are published or not. The documents may come from teaching and research institutions in France or abroad, or from public or private research centers.
L'archive ouverte pluridisciplinaire HAL, est destinée au dépôt et à la diffusion de documents scientifiques de niveau recherche, publiés ou non, émanant des établissements d'enseignement et de recherche français ou étrangers, des laboratoires publics ou privés. 


\title{
Laser assisted machining: process control based on real-time surface temperature measurements
}

\author{
M. IGNATIEV, L. OKOROKOV, I. SMUROV*, V. MARTINO*, G. BERTOLON* and \\ G. FL,AMANT**
}

Baikov's Institute of Metallurgy, Russian Academy of Sciences, Leninsky Prospect 49, 117911 Moscow, Russia

${ }^{*}$ Ecole Nationale d'Ingénieurs de Saint-Etienne, 42023 Saint-Etienne cedex 2, France

** Institut de Science et de Génie des Matériaux et Procédés, CNRS, BP. 5, Odeillo, 66125 Font-Romeu cedex, France

\section{INTRODUCTION}

The cutting temperature $\theta_{c}$ (temperature at the contact point of a tool with treated material) is one of the most important parameters for Laser Assisted Machining (LAM). The cutting temperature $\theta_{c}$ comprises the additional surface heating temperature $\theta_{h}$ and the temperature $\theta_{d}$ caused by the processes of deformation and friction in the zone of a chip formation $\left(\theta_{c} \sim \theta_{h}+\theta_{d}\right)[1]$.

Among the main aims of the paper are:

-to investigate the influence of LAM parameters variations on surface heating temperature $\theta_{h}$ using high-speed (response time $200 \mu s)$ high-spatial resolution (200 fm) pyrometer [2];

-to study the relationship between surface heating temperature $\theta_{h}$ and cutting temperature $\theta_{c}$ (measured by themocouple);

-to choice the most sensitive LAM parameters and corresponding laws for on-line control of the optimum cutting temperature $\theta_{c}$. 2. RESULTS AND DISCUSSION

LAM setup schematic is shown in Fig.1. The workpieces were cylinders with length 50-150 mm and diameter 15-20 mm of various materials: Mo[111], W[111], Ti, zirconium hydride, ceramic materials, and special steels.

The dependencies of the average heating temperature (for Mo and $W$ ) on laser power and cutting speed are presented in Fig. 2 and 3 correspondingly. Note that the surface temperature 
is olightly affected by cutting speed variation, but it depends strongly on the value of laser power. The optimum ranges for the cutting temperature were determined from the tool wear resistance tests at conditions of high quality of machining. These ranges are shown by hatching in Fig.4,5. The optimum heating temperatures for Mo fall in the broad range (between $1600-1800^{\circ} \mathrm{K}$ ) and it is practically independent of cutting speed. The optimum heating temperatures for $W$ must be kept at $1550^{\circ} \pm 25^{\circ} \mathrm{K}$; in such a case the cutting speed can vary in the narrow range 65-80 m/min. Hence, the main principle of process control for IAM is to keep heating and cutting temperatures within optimum ranges. Any heating temperature deviation must be compensated by: (a)-laser power increase (decrease); (b)variation of the diatance $L$ between center of the focus spot and the cutter edge. The second opportunity has the minimum response time and higher sensitivity because of the sharp dependence of the cutting temperature on the distance $I$ (Fig.6). The distance variation can be easy produced by rotation of the focusing mirror (4) Fig.1.

\section{CONCLUSTON}

The algorithm for LAM control based on real-time temperature measurements consists of the following steps:

1.Measurement of the heating temperature at the center of the focus spot by high-speed high-spatial resolution pyrometer.

2.Filtration of the signal noise (temperature oscillations) and definition of the average heating temperature.

3.Comparison of the average heating temperature with the required levels obtained from the beforehand prepared data base.

4. Definition of the new distance between the center of the focus spot and the cutter edge (if the heating temperature is outside of the optimum range).

5. Rotation of focusing mirror to the required angle.

References

1.I.Smurov, L.V.Okorokov, in Laser Application for Mechanical Industry, NATO ASI Series, Series E: Applied Sciences, v.238, (Kluwer Academic Publishers, Dordrecht, 1993), pp.151-163.

2.M.Ignatiev, I.Smurov, and others, in Proceedings of ECLAT 92, Götingen, 1992 (DGM, Oberurse1, 1991), pp.15- 20. 


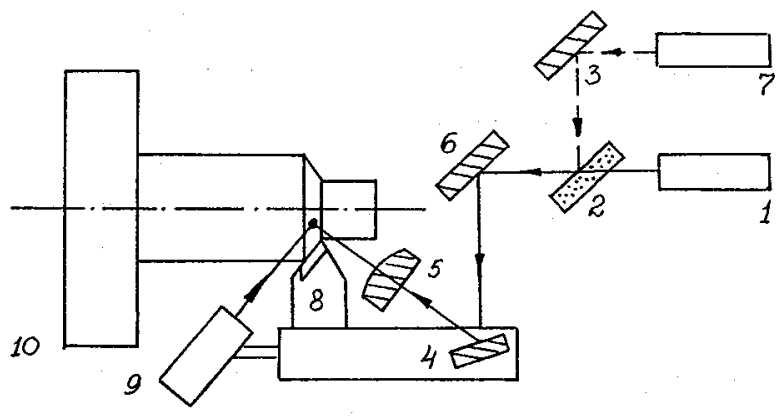

Fig-1 LAM setup diagram: (1) $-\mathrm{CO}_{2}$ laser; (2)-(6) optical system: mirrors, lens; (7)He-Ne laser; (8)cutter; (9)pyrometer; (10) lathe.

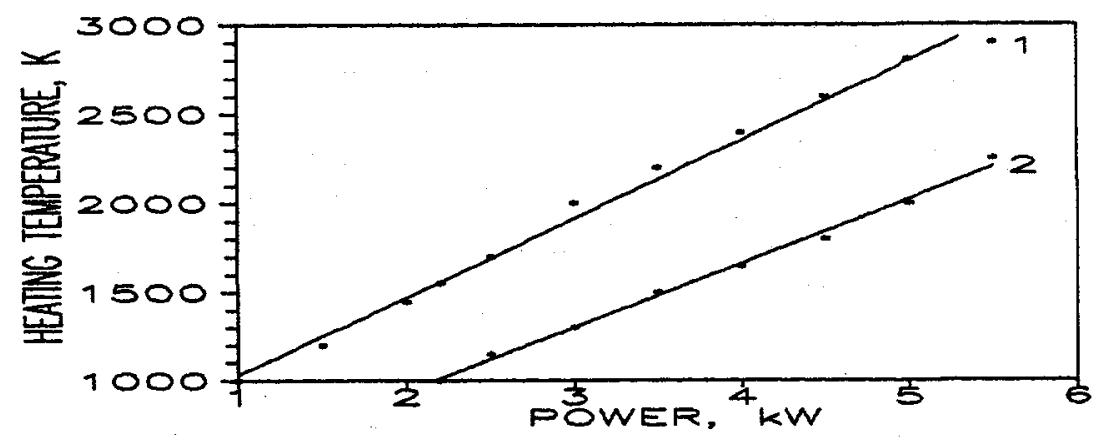

Fig-2 Average heating temperature (at the center of the focus spot) versus laser power. Cutting speed $V=0.5 \mathrm{~m} / \mathrm{s}$. Diameter of the laser focus spot $d=0.5 \times 10^{-3} \mathrm{~m}$. (1) -Mo; (2) $-\mathrm{W}$.

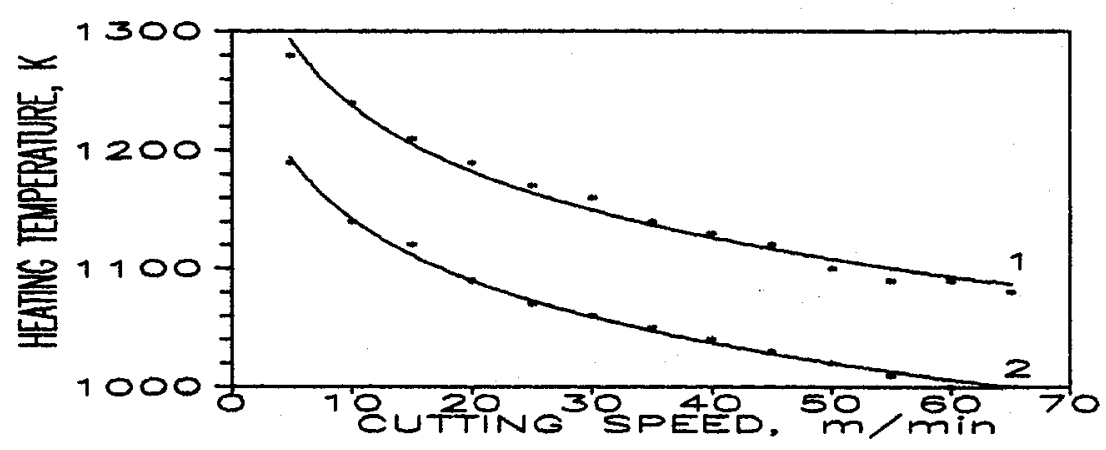

Fig. 3 Average heating temperature (distance from the center of the focus spot $L=0.5 \times 10^{-3} \mathrm{~m}$ ) versus cutting speed. $d=0.5 \times 10^{-3}$. (1) $-\mathrm{Mo}, \mathrm{P}=3.4 \mathrm{~kW}$; (2) $-\mathrm{W}, P=4.6 \mathrm{~kW}$. 


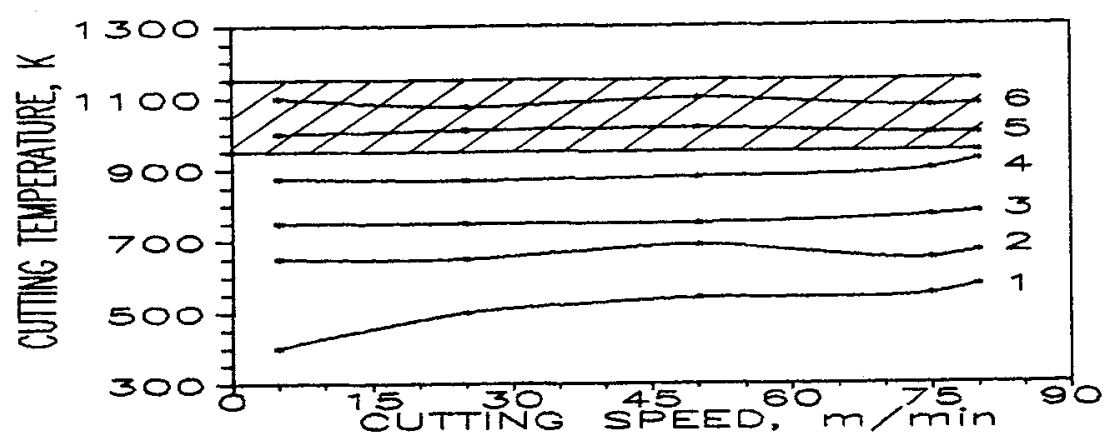

Fig.4 Cutting temperature versus cutting speed. Material-Mo. Cutting depth-z=0.2 mm. Cutting feed-s=0.05 $\mathrm{mm} / \mathrm{rev}$. $\mathrm{L}=0.5 \times 10^{-3} \mathrm{~m} . \quad \mathrm{d}=0.5 \times 10^{-3} . \quad(1)-\theta_{\mathrm{h}}=300 \quad \mathrm{~K} ; \quad$ (2) $-\theta_{\mathrm{h}}=1300 \quad \mathrm{~K}$; (3) $-\theta_{h}=1400 \mathrm{~K} ;(4)-\theta_{h}=1500 \mathrm{~K} ;(5)-\theta_{h}=1600 \mathrm{~K} ;(6)-\theta_{h}=1700 \mathrm{~K}$;

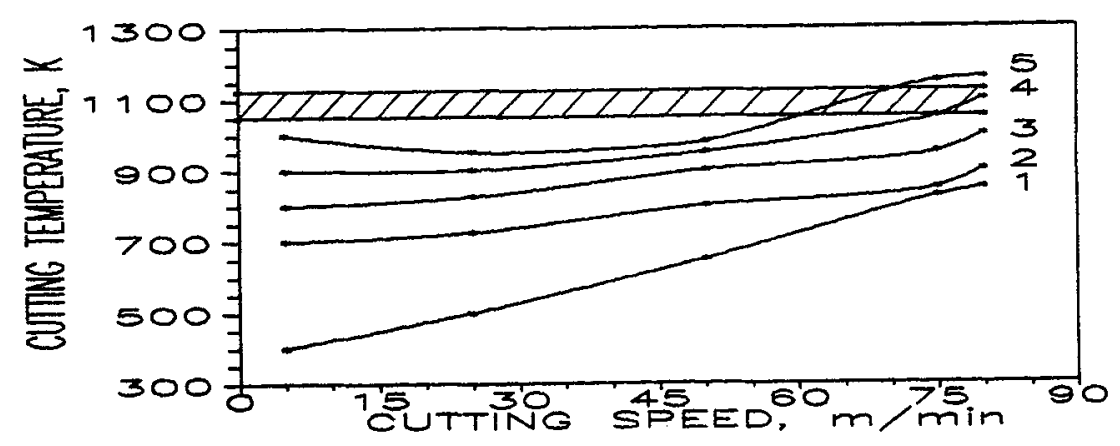

Fig.5 Cutting temperature versus cutting speed. Material-w. $z=0.2 \mathrm{~mm} . S=0.05 \mathrm{~mm} / \mathrm{rev} . \mathrm{L}=0.5 \times 10^{-3} \mathrm{~m} . \mathrm{d}=0.5 \times 10^{-3} .(1)-\theta_{\mathrm{h}}=300 \mathrm{~K}$; (2) $-\theta_{h}=1300 \mathrm{~K} ;(3)-\theta_{h}=1400 \mathrm{~K} ;$ (4) $-\theta_{h}=1500 \mathrm{~K} ;(5)-\theta_{h}=1600 \mathrm{~K}$.

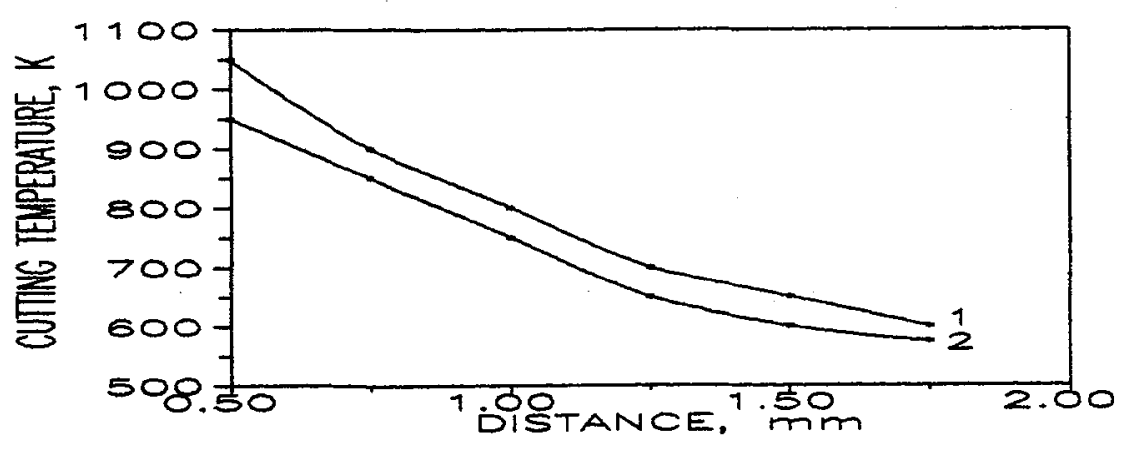

Fig. 6 Cutting temperature versus distance between the center of the focus spot and the cutter edge. $\theta_{h}=1600 \mathrm{~K} . V=60 \mathrm{~m} / \mathrm{s} . \quad z=0.2$ $\mathrm{mm}$. $S=0.05 \mathrm{~mm} / \mathrm{rev}$. (1) $-\mathrm{W}$; (2) - Mo. 